Portland State University

PDXScholar

1977

\title{
A One Case Study of a Fifteen Year Old Boy in Residential Treatment in the State of Oregon
}

\author{
Edward S. Cote \\ Portland State University
}

Follow this and additional works at: https://pdxscholar.library.pdx.edu/open_access_etds

Part of the Social Work Commons

Let us know how access to this document benefits you.

\section{Recommended Citation}

Cote, Edward S., "A One Case Study of a Fifteen Year Old Boy in Residential Treatment in the State of Oregon" (1977). Dissertations and Theses. Paper 1898.

https://doi.org/10.15760/etd.1898

This Thesis is brought to you for free and open access. It has been accepted for inclusion in Dissertations and Theses by an authorized administrator of PDXScholar. Please contact us if we can make this document more accessible: pdxscholar@pdx.edu. 


\title{
A ONE CASE STUDY OF A FIFTEEN YEAR OLD BOY IN RESIDENTIAL TREATMENT IN THE STATE OF OREGON
}

by

EDWARD S. COTE

\author{
A report submitted in partial fulfillment of the \\ requirements for the degree of \\ MASTER OF SOCIAL WORK
}

Portland State University

1977 


\section{ACKNOWLEDGMENTS}

A note of thank you is extended to the following individuals for their assistance with this study. Allowing for easy access to records and giving time for personal interviews was especially appreciated.

1. Children's Services Division, State of Oregon

Linda Hogan, Casework Supervisor, Liaison Unit

Dale Paulson, Caseworker, Liaison Unit, Portland, Oregon.

2. Hank Dufort, Intake Caseworker, Children's Farm Home, Corvallis, Oregon

3. Julie Pleken, M. S. W., Program Director of Tucker Cottage, Albertina Kerr Center. 
TABLE OF CONTENTS

PAGE

ACKNOWLEDGMENT . . . . . . . . . . . . . . . ii

LIST OF TABLES . . . . . . . . . . . . . . . . iv

CHAPTER

I. INTRODUCTION . . . . . . . . . . 1

II. REVIEW OF THE LITERATURE . . . . 5

Residential Treatment . . . . . 5

The Type of Child Best Suited For

Care . . . . . . . . . 7

Problems of Residential Care . . . 9

Cost of Residential Treatment . . : 11

III. DESCRIPTION OF THE SUBJECT . . . 13

IV. THE SYSTEM RESPONDS . . . . . . . . 18

V. GOALS OF THE CHILDREN'S SERVICES

DIVISION OF THE STATE OF OREGON : 28

VI. MEANS UTILIZED TO SECURE PLACEMENTS AND IMPLEMENT TREATMENT

GOALS . . . . . . . . . . 33

BIBLIOGRAPHY . . . . . . . . . . . . . . 60

I. WORKS CITED ............ 60

II. REFERENCES . . . . . . . . . 62 


\section{LIST OF TABLES}

TABLE

PAGE

I. Length of Stay in Three Categories

of Placement . . . . . . . . .

II. Financial Justification for Children's

Farm Home . . . . . . . . .

III. Cost of Care at the Children's Farm Home.

IV. Cost of Care at Tucker Cottage of The

Albertina Kerr Center........

V. Payment to the Albertina Kerr Center

May, 1973 through February, 1976 . .

VI. Total Payment Authorized for Period

May, 1973 through July, 1976 . . . 
CHAPTER I

\section{INTRODUCTION}

Residential treatment is today trembling on the brink of becoming a science. Until recently, it was about at the same level of sophistication as say, motherhood; it was humane, intimate, complicated and important, but rather undescribable and unqualified - some people did it well, some poorly, and it was hard to tell anyone "how to." 1

This study concerns one fifteen year old boy in residential treatment in the State of Oregon. He is a diabetic, has been called emotionally disturbed and for nine years and eight months has been a ward of the Children's Services Division.

Residential treatment for emotionally disturbed adolescents is one of the most controversial subjects confronting psychologists, social workers, legislators, families, and the general public. Controversy comes from the many questions yet to be agreed on. Questions such as: How much should it cost? Do residential treatment centers utilize individual treatment plans? Which adolescents are appropriate candidates for residential care? What means are appropriate to secure residential placements? Have residential treatment centers developed a significant degree of political clout? 
Are the "impossible" cases used to bargain for higher payment fees? What happens when the adolescent residents reach the age of legal emancipation? Are adolescents who spend long periods of time in residential treatment centers prepared socially, vocationally, educationally, and financially to assume the roles and responsibilities of adulthood?

This study will address some of these questions, however it will not be a comprehensive examination of all of them. It will be done on the basis of a case study of a fifteen year old boy who is in residential treatment in the State of Oregon.

The study is at the request of the program Director of The Tucker Cottage residential treatment program of The Albertina Kerr Center in Portland, Oregon. The emphasis of the analysis will be on the cost of care and the process of securing a placement following his discharge from Tucker Cottage. The study represents an assessment of this boy's development since 1965. Particular attention will be focused on the period between May 1, 1973 and July 31, 1976. An assessment of the placement process and how payment rates were established will be of particular importance. Additionally an over-all assessment of the processes, expenses, and various treatment modalities will be made to determine what nine years and eight months of treatment have meant in terms of the growth and development of this adolescent. 
The material presented was gathered by study of case records at Tucker Cottage Residential Treatment Center, Children's Services Division, Liaison Unit and The Children's Farm Home, Corvallis, Oregon. Additionally, personal interviews were conducted with staff of the se agencies and with the subject of the study.

In the reading of records and the interviewing of staff members, specific information was sought. This information included basic family background, diagnostic impressions of the subject, a chronological history of his placements, the total cost of care in two residential treatment centers and the roles and responsibilities of those involved in this case. This included social service agency staff, juvenile court staff, legal counsel and medical personnel.

The research also sought to answer questions such as: Which agencies authorized payment? Which agencies made decisions regarding, treatment and which assumed responsibility for monitoring the progress of treatment? What were the differences in diagnostic impressions of the subject in 1966 and now in 1976?

These questions are important because of the number of children in such a system. The questions raise important issues with respect to professional accountability. Answering the se questions should shed some light on bureaucratic and institutional functions, even those disguised as residential treatment facilities. 


\author{
CHAPTER II \\ REVIEW OF THE LITERATURE
}

The intent of this chapter is to briefly discuss several broad issues in relation to residential care. It will be a general overview of residential treatment as contrasted to the discussion of the specific case which will be the subject of the study. For our purposes then, the material presented will try to give a review of the topic while trying to answer several questions. The first question, what is residential treatment? The following questions. need to be raised as well: The appropriateness of residential treatment, the type of child who can be served by this treatment method, the pitfalls of residential care and the cost of care. A review of the literature has been done in order to help the reader become acquainted with the issues discussed in the study.

\title{
RESIDENTIAL TREATMENT
}

Residential treatment is the term given to the method of treating children and adults by removing them from their own home or foster home and placing them in a living situation where their material and psychological needs are attended to. Residential 
treatment differs significantly from outpatient and other treatment methods because the treatment center takes responsibility for total management of the child's current experiences-in-living. It attempts to monitor and modify, for therapeutic gain, all the facets of the child's life. ${ }^{2}$

Milieu therapy is used to treat the total child by creating for him a safe environment in which he can learn to change his disturbed patterns of interaction. This treatment includes every facet of the child's life - - waking, bathing, eating, toileting, schooling, and playing. Evertz Mayer (1975) in "Social Control in the Residential Treatment of Adolescents in Residential Care: A Dilemma," states that the effectiveness of residential care rests on the adolescent's participation in the daily living routine at the center. Essentially, the child care institution tries to make up for the emotional deprivations suffered by the child in his earlier life and to help him avoid similar situations in his adult life. This work is carried out by the child care staff twenty-four hours a day. The review of the litexature showed that of all the features of the residential institution the most important component is that of the child care staff. "The soul of an institution is its philosophy, only as it is practiced by the staff. $"{ }^{3}$ 
In Growing up in Garden Court, Lois Murphy feels that the major test of a residential treatment center is whether it helps a child become conscious of his frustrations and thus reduces the frequency and intensity of his blind rage and he learns new ways of managing it. ${ }^{4}$ Child care workers, teachers, and psychologists know that a child while feeling anger toward a world that cannot be endured is at the same time hungry for love. Along with his angry repudiation of the world, all too often he hates himself for his failures, his hasty feelings and his destructive deeds. Child care. workers teach children how to love. Learning to talk with children themselves contributes to being able to help them. We must not get carried away with the emotional and mental attitudes that are. helpful in working with disturbed children.

Bruno Bettleheim reminds us, "Love is not enough, one must not permit himself to neglect the most careful planning and doing. ". .

\section{THE TYPE OF CHILD BEST SUITED FOR CARE}

The following is a description of the characteristics of children and families best suited for residential treatment. According to Martin (1976) in "Uses of Residential Care," ${ }^{5}$ it has been his experience that children from latency through adolescence are in the age group most likely to gain from residential treatment. This view is shared by others. 
Residential treatment is alleged to be suitable for disturbed adolescents overburdened with multitudinous problems. Over time the family may lose its ability to cope with the child and must look beyond the family for help. The degree to which the child is actingout also is a factor that influences placement into a residential setting. A child who cannot be safely contained in a community placement cannot benefit from the treatment that is available in that community. Children who are locked into a parent-child relationship that is neurotic cannot benefit from local outpatient treatment. Children who have been scapegoated by their families and by the community are good candidates for residential treatment where they can be protected from the hostile forces in their environment. The following three characteristics are usually common to candidates for residential treatment: (1) The need for a thorough diagnosis of ability and functioning; (2) the need for remedial education, and (3) incapacity from psychological disorders to such a degree that his growth and development become seriously impaired.

Earlier reference was made indicating that residential treatment can be more beneficial to an older child. Puberty is often a time in a child's life when children with severe emotional problems have exaggerated reactions. Their greater anxiety over changes taking place in their bodies exaggerates the basic emotional difficulties and may overwhelm them with feelings they cannot cope with. ${ }^{6}$ 
A disturbed child has all the developmental conflicts of a normal child and has not had enough help, for one reason or another, to master basic social skills or cope with ordinary tasks. Such children also experience difficulty in trying to get along with peers or siblings. They cannot do tasks that other children learn to do.

Children who would be placed in group care are children who cannot depend on families and who cannot utilize effective inte rpersonal relationships. 7

\section{PROBLEMS OF RESIDENTIAL CARE}

There are some inherent problems in a residential setting. These can range from the attitude of the child to the cost that it takes to provide quality treatment. Often times residential care is the treatment of last resort. The child has failed in numerous other placements. Those working with him have given up. The task of ego-building becomes even more difficult for a youngster in such a situation. His low self-esteem is compounded by the fact that he knows no one else wants him.

According to Bettleheim, the central issue in all functional disturbances is the absence of self-respect. ${ }^{8}$. Yet in order to gain treatment most clients are minus self-respect by virtue of the process of arriving at group care. Residential treatment becomes 
the last chance. The treatment center is then placed in the role of trying to meet the needs of the children as identified by the professional community.

Gabriel D'Amato makes the comment that the residential cente $x$ often times is "too far removed from where $90 \%$ of the problems are to be solved. 19 Once the family and the community have removed the child, the tendency may be to forget him; The disturbed child is then neglected. There is too little coordination. and organization of available resources. "Out of sight, out of mind." The child gets shifted from one place to another with the hope that the new placement will work, that someone else will be responsible for the child and that he won't come back, too soon at least. 10

Not infrequently, children come into residential situations where no normal parental ties exist. In such cases the tendency. may be to move too hurriedly to substitute parents, without first exploring the possibility of making contact with other blood relatives. Probably nothing is so difficult for a child to assimilate than the sense that he belongs nowhere and to no one. A child needs to be reassured that he is related to some persons, even if they are distant figures and cannot provide a home for him. 11

Another problem posed from the outsider's point of view would be one of development. Is it possible to provide the essential. elements necessary for healthy development? Murphy cites this 
need when she states,

Children's needs include opportunity for developing a mastery of culturally expected motor skills, needs to relate to others, needs to feel accepted by other children and valued by adults. 12

Bettleheim feels that mental hospitals permit patients some degree of mastery within their confines, but the hospital does not restore the patient's ability to cope with higher complexity. ${ }^{13}$ Such ability brought about by ego strength includes the capacity to appraise situations in which the child finds himself, to size up the potential satisfactions or frustrations of each situation, to make reasonable choices and to decide on appropriate goals and workable steps to reach those goals. 14

\section{COST OF RESIDENTIAL TREATMENT}

Among the problems facing residential care facilities are those of cost. In order to provide the quality of child care and treatment demanded, cost becomes a significant factor, both for the patient or sponsoring agency and the facility itself.

Some cost figures may give the reader a reference point. These figures have been lifted out of context and are, in some cases, ten years old. However, the basis for calculation seems to be the same. The costs are roughly cost per patient year of residential treatment. 
Bruno Bettleheim, in his book A Home for the Heart (1974), an extensive description of his Orthogenic school in Chicago, states that as late as 1970 it cost $\$ 8,000$ a year to maintain a patient. 15 This figure includes everything; staff, clothing, treatment and shelter. By contrast, in a study conducted by the Child Welfare League of America in 1961, which was a comparative analysis of twenty-one residential treatment centers and two the rapeutic day schools, the costs per child ranged from $\$ 3,900$ to $\$ 17,947$ per year. 16 In 1970 residential treatment centers that are members of The American Association for Children's Residential Centers were polled. Of fifteen centers, the lowest cost per child was $\$ 7,289$ per year and the highest, $\$ 18,000.17$

All of the aforementioned aspects were discussed to give a general overview of residential treatment. The study will now address some of the se issues as they relate to an in-depth study of. one child in residential treatment. 


\section{CHAPTER III}

\section{DESCRIPTION OF THE SUBJECT}

The following information was taken from case record descriptions of the subject of the study. In order to protect the confidentiality of the subject, he shall be referred to as "Tim."

Tim is small in size for a boy of his age, has light brown hair and wears braces. An initial impression made upon meeting him was that he was thin and rather fragile in appearance. One initially questions his social skills due to his inappropriate greeting extended to strangers. There are no other distinguishing characteristics.

Tim was fifteen years old in 1976, he was born in Portland, Oregon in 1961. Tim's parents were married in 1960 and two siblings were born to this union. Tim in 1961 and a sister in 1962. One other child was present in the family home, an illegitimate daughter born to Tim's mother in 1955. Tim's father is a sixty-four year old merchant seaman who was also born in Portland, Oregon. He has not had any meaningful contact with Tim since 1966 . Tim's mother was born in 1921 in Council Bluffs, Iowa and died in 1969 in Portland, Oregon. 
The initial social service contact with Tim's family was in December of 1966 when Tim's mother applied for Aid to Dependent Children through the Division of Public Welfare in Portland, Oregon. She was separated from Tim's father and complaining of an unhappy marriage. Divorce papers were filed in 1968; however, a reconciliation took place prior to Tim's mother's death in 1969.

The second social service intervention in the family was in October of 1968 when the oldest daughter, born in 1955, was placed in foster care. This placement was necessitated by the inability of the mother to provide the care, due to illness. This sister was placed in four foster homes prior to her eventual placement at Villa St. Rose, residential treatment center for adolescent girls. She remained there until the age of eighteen, then married. Tim's full sister was also placed in foster care in 1968 and has resided in the same foster home since 1969. She has not maintained contact with him.

During the initial application for public assistance in 1966 , Tim was at Providence Hospital where he was undergoing treatment for diabetes when the initial referral to Children's Services Division was made. The process which followed will be discussed in Chapter IV.

The only other significant person in Tim's family was an aunt, sister of 'Tim's father. There appears to have been some 
effort on her part to assist Tim's father with child care during his wife's terminal illness. Despite her efforts, the family was eventually separated. She has maintained some contact with Tim over the last ten years and has been the only family contact available to Tim. The staff of both Tucker Cottage and Children's Farm Home considered her efforts as minimal.

Diagnostically, Tim has been called a manipulator, one who has a low opinion of himself and subsequently a distrust of others. He has been called "emotionally disturbed" (a label often applied). However, a specific diagnostic label has never been given. Most importantly, Tim is a diabetic which has been the cause factor of many of the problems, particularily those concerning agencies ${ }^{\prime}$ abilities to locate adequate facilities which are able to cope with the magnitude of physical and psychological difficulties associated with adolescent diabetes.

A professional psychological evaluation was done in November of 1968 when Tim was seven years and nine months old. On the Wechsler Intelligence Scale for Children (WISC) he obtained a verbal I.Q. score of 105 , a performance of 117 and a full scale of 112 . The Peabody Picture Vocabulary Test was also given at that time. He obtained a recognition vocabulary age of seven years and ten months and a recognition vocabulary score of 99.

At no time in the progress reports or treatment summaries 
was mention made or a relationship established between diabetes and related psychological problems commonly associated. Repeatedly, mention was made of the outward manifestations of the behavioral characteristics of this adolescent and why they we re so extremely difficult for a child care staff to cope with.

As Geist states, "With the increased assertiveness, the adolescent may use his diabetes as a weapon against parental authority. "18

The 1968 psychological evaluation again mentions Tim's low self-esteem. This trait does not appear to be present to a degree atypical of adolescent diabetics. "The undersized, slow developing adolescent usually attributes his delayed growth pattern to his diabetes and may feel inferior during this period in which rapid growth and maturation are normal. "19 Tim's diabetic. condition has compounded his identity crisis and made this most significant developmental milestone more difficult than that of a non-diabetic adolescent.

Adolescents typically rely on their body image as a source of their identity. However, little continuity is typically provided by the body during these years. As Wenar states,

The more his body departs from the culturally determined ideal the more he is distressed by specific sexual developments and the general turmoil of the transition status. He becomes more sensitive to adults and peers 
and they more insensitive to him. The body may become a source of dissatisfaction and self-consciousness. 20

Consequently, an adolescent suffering this kind of turmoil might follow another characteristic pattern of people with weak egos -that pattern being neglect of diet not only for primary pleasure but for a secondary gain, attention.

Having described the subject, the analysis will now proceed to a chronological history of Children's Services Division's involvement with Tim. More extensive descriptive, diagnostic, and social assessments will be discussed during this analysis. However, it is significant to note that at no point in the nine-year involvement with Tim was he ever adjudicated as delinquent. 


\section{CHAPTER IV}

\section{THE SYSTEM RESPONDS}

As previously mentioned, the initial referral to the Children's Services Division was made on December 5, 1966, when Tim was five years old. Tim was hospitalized at Providence Hospital with a diagnosis of diabetes and had been at the hospital for two weeks. The hospital staff felt that the natural mother lacked sufficient understanding of diabetes and did not demonstrate an interest in learning more about the illness. She was also having a difficult time coping with her own illness, cancer.

The following is a chronological list of the seventeen placements made by The Children's Services Division since the initial referral.

1. December 19, 1966 to January 24, 1967... Tim was placed in a temporary receiving home until a long-term foster home could be located. A death in this initial foster home necessitated an early removal.

2. January 24,1967 to July $21,1967 \ldots$ A second place ment was in a county foster home. These foster parents we re eventually unable to cope with six year old Tim. 
They complained that he was aggressive, had numerous temper outbursts and was generally unresponsive to any discipline.

3. July 21, 1967 to September 14, 1967... Placed at Waverly Children's Home, a residential care facility.

4. September 14, 1967 to April 9, 1968... A third unsuccessful foster home placement.

5. April 9, 1968 to November, 1968... Placed at Waverly Children's Home.

6. November, 1968 to December, 1969... Placed at Edgefield Lodge residential treatment program. During this placement, Tim continued to go to Waverly Children's Home for weekends until an appropriate foster home was located 'by Children's Services Division. Tim began running away from Waverly Children's Home in September of 1969 at the age of nine. This was the first recorded episode of any-run-away activities.

7. December, 1969 to May, 1970... Once again placed in foster care. This foster home met with Edgefield Lodge staff and attempted to learn more about Tim prior to his placement. These foster parents began having Tim for weekends in December of 1969 and he was placed in February of 1970. By May of 1970 the foster parents 
reported the same sort of manipulation, self-

destructiveness and lack of any appropriate social skills.

They were unable to cope with the difficulties and asked

that Tim be removed from their home.

8. May, 1970 to October, 1970... Placed in another foster

home. These foster parents also worked with Edgefield

Lodge staff. A staff member from Edgefield Lodge

accompanied Tim to the public school program. By

October of 1970 , both the foster home and the public

school found Tim to be unmanageable.

9. October, 1970 to April 26, 1971... Placed at Multnomah

County Juvenile Detention Center. Tim remained there for six months and twenty-six days. The program manager of Tucker Cottage, felt that it was during this period that Tim's situation became one of politics rather than humanity. A child advocacy committee was formed to advocate for Tim and others who were spending unnecessarily long periods of time in the detention center. This committee was formed through the efforts of Judge Jean Lewis and The Children's Services Division and was funded by the Emergency Board of the Oregon State Legislature. Three of the children they advocated for, including Tim, now reside at the Children's Farm Home 
in Corvallis, Oregon. The program manager of the Tucker Cottage program of the Albertina Kerr Center stated that this advocacy committee was ultimately responsible for the formation of the Tucker Cottage program and Tim's eventual placement there. The administrator of the Albertina Kerr Center was a member of this advocacy committee.

It is beyond the scope of this report to inquire into the implications or arrangements of the advocacy committee in relation to the program which ensued, except to state the tie with Tim's case.

10. April 26, 1971 to September 9, 1971... Placed at Parry Center residential treatment program. They requested his removal after four months of unmanageability. In a letter, the director of the Center stated. that it was felt that Tim had serious ego defects. Their opinion was that these defects were manifested mainly by Tim's inability to form close relationships or attachments and in the use of diabetes as a manipulative device. Tim specifically would refuse to eat or would purposefully eat the wrong foods and would frequently refuse to take insulin.

11. September 9, 1971 to December, 1971... Tim was returned to the Juvenile Detention Center. 
12. December, 1971 to April, 1972... Began weekend visits to another foster home and placed in February of 1972. Again complaints of unmanageability necessitated his removal.

13. April, 1972 to September, 1972... Another five months in the juvenile detention center.

14. September 1, 1972 to April, 1973... Placed at Montanari Residential Treatment Center in Hialeah, Florida. A special approval for the out-of-state placement brought Tim's situation into the public's awareness mainly through newspaper articles. The Florida center requested his removal by February of 1973 . They stated that he was unmanageable, moved to various cottages to live and was continually in and out of intensive treatment with diabetic reactions.

15. April, 1973 to May, 1973... Placed at Multnomah County Juvenile Detention Center. Tucker Cottage was being prepared to accept their first placements.

16. May 25, 1973 to February 16, 1973... Placed at Tucker Cottage residential treatment program of the Albertina Kerr Center.

17. February 16, 1976 to present... Placed at Children's Farm Home in Corvallis, Oregon. 
Table I is a graphic presentation of Tim's length of stay in three categories of placement. It was computed to include the period from December 19, 1966 through September of 1976.

TABLE I

LENGTH OF STAY IN THREE CATEGORIES

OF PLACEMENT

\begin{tabular}{lcc}
\hline Category & Number of Placements & Total Time \\
\hline Foster Care & 6 & 26 months \\
Residential Treatment Centers & 7 & 73 months \\
Juvenile Detention & 4 & 17 months \\
Total time of wardship & & 9 years 8 months \\
Total number of placements & 17 & \\
\hline
\end{tabular}

It is significant to note that at one point during the nine-year and eight-month involvement the juvenile detention center also refused to keep Tim. During that period Tim spent the weekends at The University of Oregon Medical School Hospital and spent the week days at Edgefield Lodge.

Once Tim was finally accepted for placement at Tucker Cottage at the age of twelve, he. was only ten months from the maximum age (thirteen) for. which Tucker Cottage was established to serve. The Tucker Cottage program was established to serve 
seven emotionally disturbed boys; ages 10 through 13 . Its program description at the Children's Services Division reads:

Common behavioral problems at the time of referral include truancy, adjudicated delinquency, chronic runaway and the inability to form close relationships. Inappropriate referrals are considered to be those individuals whose tested IQ is below 90. The program is a "lock-up" situation for those boys who cannot be treated in an open setting. The treatment model is token economy behavior modification and the average length of stay is one and onehalf years.

Tim was in residence there two years and ten months and remained until the age of fifteen, despite the age limitation. He was the oldest boy in the program during the majority of his placement there.

Locating a facility willing to accept Tim following his stay at Tucker Cottage was a major difficulty. Twenty facilities were contacted by the Children's Services Division. These twenty in-. cluded:

Albany Child Care Center

Belloni Ranch

Multnomah Boys Center

Cordero Youth Care Center

Frontier House

J - Bar - J Ranch

Klamath Lake County Youth Ranch

Lane County Youth Care Centers, Inc. 
Mid-Valley Adolescent Treatment Center

Mt. View Boy's Ranch

Parrott Creek Ranch

Rainbow Lodge

Star Gulch Ranch

The Inn Home for Boys

The Next Door, Inc.

Umatilla County Boys Ranch

Youth Adventures

Portland Youth for Christ

Alfred Yaun Child Care Center

Children's Farm Home

Children's Farm Home did finally accept Tim for placement.

The details of this acceptance will be discussed in Chapter VI.

It has been evident to the researcher that most of those involved with this process became advocates for Tim. Social work staff at both The Albertina Kerr Center and The Children's Services Division began a long process of negotiation with the juvenile court, Children's Services Division and The Children's Farm Home. The Albertina Kerr Center and Children's Services Division had to convince the Children's Farm Home that Tim did indeed have positive aspects. During the process Children's Farm Home found themselves in a position which enabled them to make demands to which 
Children's Services Division and the Mental Health Division were forced to respond.

The Children's Services Division, Tucker Cottage and the Juvenile Court were eventually to decide that Children's Farm Home was an appropriate placement.

The Children's Farm Home program description at The Children's Services Division reads:

A residential treatment program located outside Corvallis, Oregon. Co-ed program consists of three living units of boys ages 1215 and one unit for girls with a maximum capacity of ten. The treatment model is milieu the rapy with individual and group counseling available. The average length of stay is $1-1 / 2$ to 2 years. The Farm Home operates a boy's group home for aftercare. The purchase of care cost is $\$ 882.98$ monthly.

The population served includes boys and girls ages 12 to 18 who are emotionally dis turbed or delinquent. Common behavioral problems at the time of referral include runaway, out of control, school problems including truancy, adjudicated delinquency, impulsivity, isolation and drug or alcohol abuse.

They consider inappropriate referrals to be anyone with an IQ under 85, one who is actively psychotic, homicidal, overtly homosexual, or a sexually acting-out girl.

A residential school is located on the campus and staffed by the Corvallis school district.

Having described how the system has responded during the nine-year and eight-month involvement with $\mathrm{Tim}$, the analysis will 
now examine why it responded in such a manner. The intent is to examine goals which were established and to assess how Tim was described to those agencies to which he was referred for placement. 


\section{CHAPTER V}

\section{GOALS OF THE CHILDREN'S SERVICES DIVISION OF THE STATE OF OREGON}

Nowhere in the case records is there any statement of goals established by the Children's Services Division for Tim, except obtaining placements and negotiating purchase of care contracts. Throughout his seventeen placements, Tim has been involved with no fewer than three different C.S.D. offices and numerous social service personnel. C.S.D. allowed each agency which had Tim in residence to develop treatment goals for him. Even at the present time, one C.S.D. office, the liaison unit located in Portland, is carrying Tim's Case while his placement is in Corvallis, Oregon. This again shows that C.S.D. is not actively involved in the treatment planning. The treatment director of Children's Farm Home commented to the researcher about the difficulty of planning and coordinating with a C.S.D. worker located in Portland, He also felt that the coordinating was particularily important in Tim's situation as he has only $2-1 / 2$ years until he is legally emancipated thus necessitating concrete plans for his future. The Children's Farm Home expressed a desire to the researcher to have The 
Children's Services Division involved in the long-term planning effort, but they felt S. C.D. had not responded to their desires.

The staff of Tucker Cottage of the Albertina Kerr Center has taken the most active role in terms of setting treatment goals for Tim. In an interview with the program manager of Tucker Cottage, it was stated that the initial goal for Tim established by Tucker Cottage was, "To keep him alive." Even throughout the negotiations for placement at Children's Farm Home, Tucker Cottage staff were the ones who most explicitly expressed Tim's treatment needs. Their two main concerns were: (1) The development of social skills. Tim was reported to be lacking in peer relationships and in the ability to seek attention in appropriate ways. (2) Diabetes control. The need for Tim to learn to stop using his diabetes in a testing or manipulative manner was again expressed. This was felt so strongly due to the numerous hospitalizations; a result of Tim's self-destructive tendencies which had occurred during his placement at Tucker Cottage.

Both the staff of Tucker Cottage and personnel from the University of Oregon Health Sciences Center offered to assist the Children's Farm Home with this diabetes management during transfer from Tucker Cottage to Children's Farm Home. In further elaborating Tim's needs for purposes of court reports and referral summaries, Tucker Cottage staff became 
specific. They saw six needs, and these were outlined in a letter to Children's Farm Home which read:

1. A non lock-up situation.

2. Continuation of training in social skills as Tim still operated at the seven to eightyear-old level.

3. A living situation which would provide continuity through the adolescent years.

4. Clarity and consistency in the management of the diabetic condition, particularly the manipulation of adults by threatening a medical crisis.

5. Early intervention into the "testing" and escalating negative behaviors.

6. Positive adolescent models and appropriate peer relationships.

In a combined effort, Tucker Cottage staff and the Children's

Services Division took the initiative and responsibility of locating a facility to meet these needs. Although it was C.S.D. which did the majority of the negotiating, it was the Tucker Cottage staff which spoke most clearly not only to Tim's needs but also to what they saw as his strengths.

Elaborating in a letter to Children's Farm Home, on Tim's strengths, Tucker Cottage staff saw:

1. A significant change in attitude. Tim was expressing a desire to be more responsible for his own behavior outside of the lock-up situation. Tim was expressing a more positive self-image and a greäter concern for others. 
2. Intelligence and social responsibility.

3. He was highly perceptive of others' feelings.

4. He was motivated to learn and do well. He was currently participating in the planning for his new living situation.

5. He was able to constructively occupy himself and make fewer demands on others.

6: That Tim responded well to people about whom he could feel secure. That is, who demonstrated their commitment and capability to care for, understand and control his behavior.

In a July, 1975 meeting between a staff member of Tucker Cottage and staff of the Children's Farm Home, the following points were made by the Tucker Cottage staff:

Basically, Tim needs a setting which will provide maximum development of insight, social skills, awareness of others and growth of selfesteem. In order to do this, the setting must possess the techniques necessary to continue his development of control over his behavior. Most importantly, the ability to set and enforce limits. The Multnomah Cottage at the Children's Farm Home is nearly ideal for Tim because it has both competent, alert staff and uses a wide array of techniques ranging from in-depth therapy sessions to a behavior rating system. There is extensive emphasis on insightful handling of interpersonal relationships which may at this point be Tim's greatest need. Their use of limit setting is virtually the same as that of Tucker Cottage which would insure minimal loss of behavioral gains made at Tucker. In short; the program is both capable of providing the services Tim needs and of controlling his behavior when necessary. My observations also led me to believe that the staff could readily learn diabetes control techniques. 
Several items are significant to note in this process of elaborating Tim's needs and strengths and of the potential for the Children's Farm Home to meet his needs. The summary states that the staff. is capable, alert, competent, and able to learn diabetes control techniques. Despite this assessment of staff competency, the actual contract negotiated included funds for two additional staff members, primarily to meet the supervision Tim required.

The Tucker Cottage staff made a specific list of six strengths which were put into written referral summaries and used to convince Children's Farm Home of Tim's positive aspects and potential. However, the treatment director of Children's Farm Home stated, in an interview, that these specific qualities were still not present. One must also keep in mind that it is the negative, manipulative and unmanageable behavior which is used to continue the special rate purchase of care payments to the Children's Farm Home. This payment system is the subject of the next chapter. 


\section{MEANS UTILIZED TO SECURE PLACEMENTS AND IMPLEMENT TREATMENT GOALS}

The process initiated to secure the placement at the Children's Farm Home was a lengthy and trying political battle. The parties involved included the staff of Tucker Cottage, the staff of Children's Farm Home, Tim's attorney, and Children's Services Division. Children's Services Division was represented by a caseworker from the West Branch office, the administrator of Children's Services Division and a representative of the Child Study and Treatment Center. Additionally, the administrator of the Mental Health Division of the Department of Human Resources and an individual from the Community Resources Section were also participants in this process.

The initial referral to the Children's Farm Home was made by a C.S.D. caseworker on April 9, 1975. A complete social summary was attached to the referral. This summary included a description of Tim's strengths and weaknesses, and a detailed history of the previous placements made by the Children's Services Division. 
The amount of public knowledge about Tim also contributed to his being well known, even by the staff of Children's Farm Home. They were aware of Tim in that two of the other youngsters, who spent long periods of time in detention and were thereby the focus of the Child Advocacy Committee, were now residents of the Children's Farm Home. The Court hearing to approve the out-of-state placement in Florida was also especially influential in informing the general public of Tim's situation.

On April 15, 1975 the C.S.D. caseworker received a written refusal from the Children's Farm Home. The refusal was signed by the administrator of Children's Farm Home and also by the intake caseworker. The reasons for non-acceptance were as follows :

1. Farm Home's inability to deal with the diabetic condition.

2. Their inability to commit to Tim that the Children's Farm Home would be his placement for as long as he needed it. This reasoning based on the fact that Tucker Cottage staff felt that this sense of belonging and security was essential to Tim.

3. The Farm Home's inability to provide Tim with good enough group/parenting milieu so as to allow for person to person relationship development, peer socialization, and social skill development.

Following this official written refusal, the intake worker telephoned C.S.D. and stated,"(1) If some current Farm Home residents could 
be placed in the community, perhaps room could be made for Tim. (2) A "special program" would have to be worked-out and funding provided by the Children's Services Division."

The initial refusal by the Children's Farm Home was accepted until June 5, 1975. At that time the manager of The Child Study and Treatment Center was notified by a state mental health specialist, writing for the administrator of the Children's Services Division that C.S.D. and the Mental Health Division would probably have to work together to make a placement. Consequently, a meeting was held on June 24, 1975 to further discuss the placement process. In attendance were representatives of the Children's Farm Home, Tucker Cottage, C.S.D. 's Child Study and Treatment Center, and the Children's Services Division. The purposes of that meeting were spelled out in a written agenda which was given to all participants.

1. To explore the Children's Farm Home as a possible placement for Tim.

2. To provide information regarding Tim's noticeable progress and continuing needs.

3. To determine what program modifications would be required to accommodate Tim andicontinue his positive growth.

It was further agreed that a "yes" or "no"! recommendation to the Court regarding placement at the Children's Farm Home would not be made at the juvenile court hearing to be held on June 25, 1975. 
The following conclusions and commitments were made in the court report:

1. The Tucker Cottage staff would continue to work with Tim and look for a placement.

2. The Children's Farm Home would continue to discuss with the Children's Services Division and the Mental Health Division. They stressed that there would not be a vacancy until at least August; however, the Children's Farm Home was no longer issuing an outright refusal to accept Tim.

3. Children's Services Division and the Mental Health Division agreed to pursue supportive resources and alternatives which would be reported to the agencies in the near future.

4. The Children's Services Division caseworker would be the point of central contact.

5. The Tucker Cottage staff would attempt to make a second site visit to the Children's Farm Home.

The court report, in general, stressed the principle that two years of progress must not be lost.

The next correspondence was submitted to the court on July 9, 1975. This report stressed that the supervisor of the Children's Farm Home's Multnomah Cottage child care staff would be meeting with the child care supervisor at Tucker Cottage. The intent of their meeting would be to assess how Multnomah Cottage might meet Tim's needs as Tucker Cottage had done: Following this meeting, on July 31,1975 , the C.S.D. case- 
worker submitted another letter to the administrator of the Children's Farm Home. He stated, "The basic problem seems to be that adding Tim to a program which already has at least two very difficult children would be unmanageable within your present staffing pattern." The C.S.D. caseworker asked, provided additional monies could be made available from the legislature, whether Children's Farm Home would accept Tim. Two points were stressed: First, the funds would be spread out between two to five boys in the program so that if one was to leave it would not cripple the program. Secondly, it was quite likely that Tim would be a long-term placement. The Children's Farm Home was a sked to submit the special rate request and to make data available as to what the Children's Farm Home would need as the Emergency Board was to begin negotiating in August of 1975.

During meetings between Tucker Cottage staff and Farm Home staff some mutual conclusions were reached. Among these was the fact that the number of staff members on duty at Multnomah Cottage was insufficient to cope with another behavioral problem. The Cottage already: had two residents who demanded almost constant attention. The fact that these two had also been in detention with Tim for long periods of time was thought to have contributed to the formation of a delinquent and hostile clique of boys. Consequently, it was assumed that the presence of these two would make Tim's 
adjustment more difficult and the emphasis had been to make his adjustment a smooth one and one aimed at increasing positive peer relationships.

The basic need then expressed was for additional staff to provide one-to-one treatment and supervision for Tim. The staffresident ratio at Tucker Cottage is two staff members to each resident, although this figure includes all supportive personnel. At the Children's Farm Home the usual ratio had been two child care staff members on each shift with an average of fourteen. residents under their supervision.

To argue for the additional funding, a memo was sent to a mental health specialist of the Children's Services Division on August 4, 1975. The C.S.D. caseworker presented part of his justification in the form of Table II, which appears on the following page. The worker further argued that what had already been spent must be considered in relation to what would likely be spent to bring Tim to adulthood; and further, that there were other children awaiting placement at Tucker Cottage costing C.S. D. \$100.00 per day for psychiatric care. The C.S.D. caseworker accepted the Children's Farm Home's request for two additional staff members and a commitment for at least a two-year placement, and submitted the recommendations as outlined in the previously mentioned memoranda of August 14, 197. 
TABLE II

FINANCIAL JUSTIFICATION FOR CHILDREN'S FARM HOME

\begin{tabular}{lrr}
\hline & Daily & \multicolumn{1}{c}{ Annual } \\
\hline Present payment to Tucker Cottage & $\$ 62.00$ & $\$ 22,630.00$ \\
Standard payment to Children's Farm Home & 30.00 & $10,950.00$ \\
Cost of two additional staff at the Farm Home & & $16,000.00$ \\
Total payment for Tim to the Farm Home & 74.00 & $26,950.00$ \\
Increase in cost over Tucker Cottage & 12.00 & $4,320.00$ \\
Cost per child (assuming 10 in Cottage) & 1.20 & 432.00 \\
\hline
\end{tabular}

In August of 1975 another report was submitted to the Multnomah County juvenile court stating that the future placement was stalled until the emergency board made a decision.

In September of 1975 another court hearing was held as had been the pattern monthly since June. The Governor of the State of Oregon was subpoenaed by Tim's attorney. The administrator of Children's Services Division spoke for the Governor and stated that C.S.D. would provide funding for an appropriate placement.

Following the September, 1975 hearing, a letter from the manager of the Mental Health Division was sent to the Albertina Kerr Center in October of 1975 . He stated that a special foster care 
payment rate of $\$ 1,000.00$ per month would be authorized for Tim. He further stated, in the letter, that the Albertina Kerr Center would provide:

1. Special transportation to schools and medical facilities.

2. Diabetic diet training.

3. Regular relief care for foster parents.

4. All back-up and social services.

5. Training to the foster parents to enable them to deal with Tim's problems.

The $\$ 1,000.00$ per month would be paid to the Albertina Kerr Center, who would determine both their portion of the fee for providing the above services and the payment to be made to the foster parents.

The special foster care assignment was given to the program manager of Tucker Cottage. She stated, in an interview, that she was not convinced of its feasibility and she saw it as a last-ditch effort of an emergent nature on the part of the Mental Health Division. No special recruitment of foster parents was initiated by Tucker Cottage. The only efforts toward this end were by the program manager of Tucker Cottage in conjunction with C.S. D. foster home finders and no families were actually interviewed. It was the opinion of the program manager of Tucker Cottage that no foster family could deal with the multitude of medical and behavioral problems presented by Tim. The C.S.D. had failed in six previous 
foster care placements, even with the assistance of the staffs of Edgefield Lodge and Waverly Children's Home. Further, during Tim's stay at Tucker Cottage three families were tried on a visiting basis and not seen as feasible placements on a long-term basis. However, it is worth noting that at no previous time was a rate of $\$ 1,000.00$ per month offered to a foster family.

Between October of 1975 and January, 1976 the funding negotiations continued. Correspondence, dated January 2, 1976 , from the administrator of Children's Farm Home to Children's Services Division indicated that Children's Farm Home was seriously negotiating with upper management of C.S.D.; that correspondence also indicated that major planning responsibility for Tim would be handled by staff of Unruh Cottage rather than Multnomah Cottage, the cottage originally considered for placement.

A contract agreement between the two agencies was finalized on January 8, 1976. It was agreed to and signed by the President of the Board of Trustees of the Children's Farm Home and the Administrator of Children's Services Division and reads as follows:

1. By adding special services for one hardto-place youth as shown in the attachment hereto, which is made a part of the regular contract with the Children's Farm Home.

2. The maximum amount which may be paid to the contractior during the term of the contract is increased from $\$ 539,916$ to $\$ 546,953$. 
a. The contractor agrees to accept one hard-to-place youth, as one of the residential care A.D.P., when reque sted by the Division's private agency unit manager. The child may possess physical, emotional, behavioral, educational, or other problems which are serious enough to make it impracticable for the child to live at home or in any other appropriate group setting regularly available to the Division.

b. Services shall include, but not be limited to, the following when required by the care plan for the child.

(1) Continuous supervision and monitoring of the child because of self-destructive behavior.

(2) Special diet.

(3) Administering or supervision of selfadministration of required prescription drugs.

(4) Medical treatment, prescription drugs.

(5) Educational tutoring.

(6) Special transportation to treatment facilities and other places as required.

(7) Specialized training for regular and relief staff.

(8) Services normally provided for other children in residential care.

c. As consideration for services provided to one hard-to-place youth, the Division will pay the contractor an amount not to exceed $\$ 7,037.00$ at the rate of $\$ 1,102.00$ per month, plus a one-time payment of $\$ 425.00$ for phase-in services, to be billed after the end of February, 1976.

The total cost of the contracted services can be seen in Table III on the following page. 
TABLE III

COST OF CARE AT THE CHILDREN'S FARM HOME

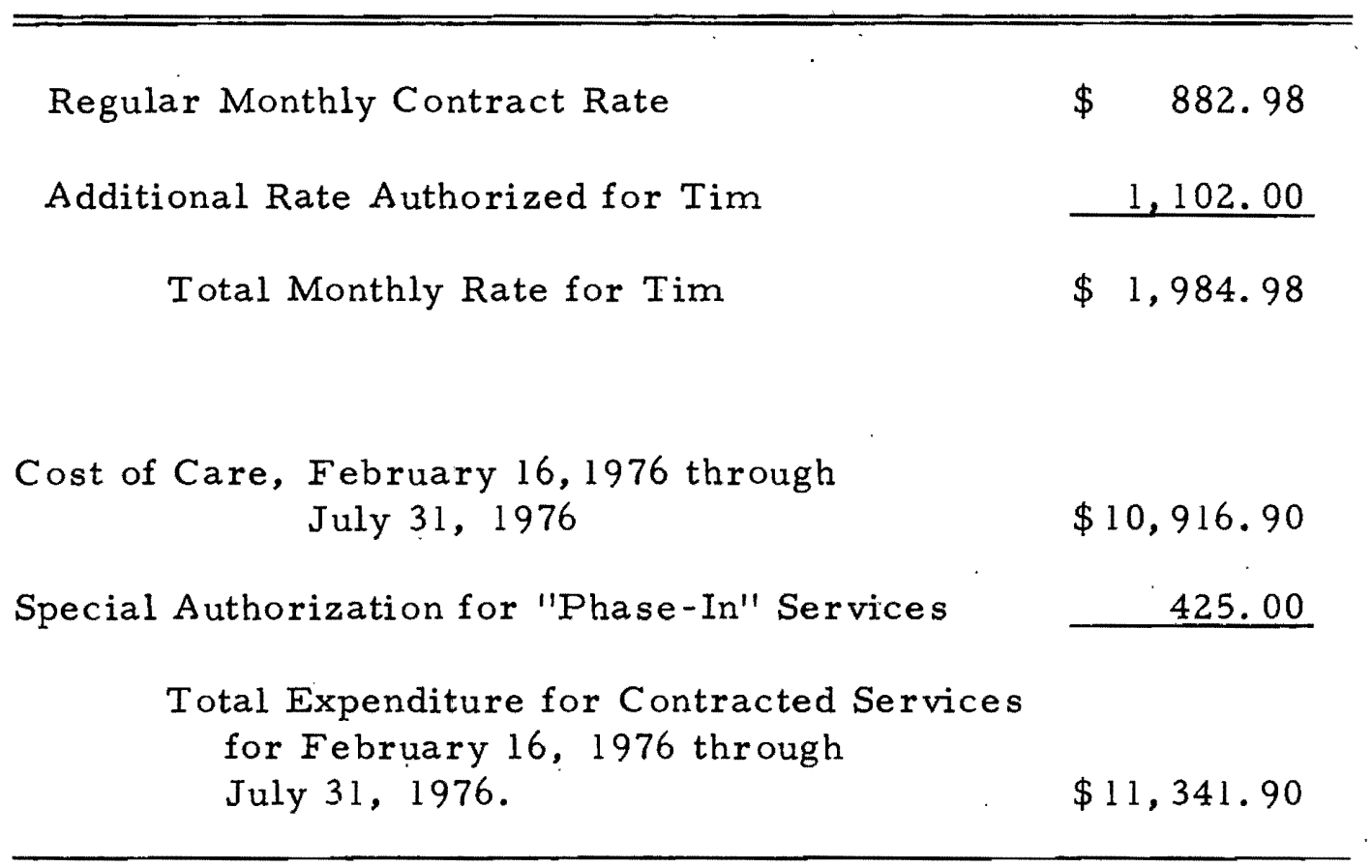

Tables IV, V, and VI detail the actual purchase of care costs at both the Tucker Cottage Program and the Children's Farm Home. A review of these tables will reveal that the total amount is $\$ 74,767.00$ for the period of May 25, 1973 through July 31, 1976 , a three year and three month period. 
TABLE IV

COST OF CARE AT TUCKER COTTAGE OF THE ALBERTINA KERR CENTER

\begin{tabular}{lr}
\hline Daily Rate of Payment & $\$$ \\
Monthly Rate & $\$ 1,922.00$ \\
Annual Rate & $\$ 23,064.00$ \\
\hline
\end{tabular}

TABLE V

PAYMENT TO THE ALBERTINA KERR CENTER MAY, 1973 THROUGH FEBRUARY, 1976

Period of Months in Residence

33

Total Expenditure

$\$ 63,426.00$

TABLE VI

TOTAL PAYMENT AUTHORIZED FOR PERIOD MAY, 1973 THROUGH JULY, 1976

\begin{tabular}{cc}
\hline \hline Amount Authorized for Tucker Cottage & $\$ 63,426.00$ \\
Amount Authorized for Children's Farm Home & $\$ 11,341.90$ \\
Total Purchase of Care Fee & $\$ 74,767.90$ \\
\hline
\end{tabular}


The following costs are not included in the tables as they are costs additional to those included in the purchase of care contracts.

\section{Medical Treatment}

This would include hospitalizations, ambulances and medications. Tim has been hospitalized on numerous occasions and uses prescription medications daily. The Title XIX Medicaid Program has covered the majority of these expenses. The payments have been vendored to the services providers. These costs have most certainly been a significant aspect when assessing the total cost of care for Tim.

\section{Dental Services}

Tim has had extensive orthodonture work and wears braces. These costs have also been paid by medicaid.

\section{Expenses for Care of a Personal Nature}

Administrative and direct service expenses of Children's Services Division, Children's Farm Home, Albertina Kerr Center, and the juvenile courts.

\section{Educational Services}

Educational services have been provided by the public school districts during Tim's stay at Tucker Cottage and the Children's 
Farm Home.

The Children's Services Division record indicates that the only client participation in the sharing of these costs has been from Tim's Supplemental Security Income. This amounts to $\$ 149.00$ per month and goes directly to C.S.D.

The establishment of a specific treatment plan following Tim's placement at the Children's Farm Home was initiated by a staff member of Tucker Cottage. The suggestions to the staff of Unruh Cottage included the following, and were stated in a letter to the Children's Farm Home:

1. Maintain a matter-of -fact attitude about the process of diabetic management.

2. Keep separate "caring feelings" for Tim from the responsibility as staff to see that he manages his diabetic condition.

3. As a treatment goal, it should be to help him develop appropriate ways of getting social reinforcement and not to rely on his diabetic condition to get attention.

4. Routines around diabetic management should be rigid and matter-of-fact.

5. Monitor Tim's reduction process (checking for sugar in urine) and injection process.

6. The Tucker staff recommends that the Farm Home staff find a way to give Tim special person-to-person reinforcement following each successful management routine.

7. No special diet is required. Be sure to Have a snack after school (fruit adequate). 
Good snack (sandwich) before bed. Cottage should have Karo syrup, peanut butter, and orange juice available.

8. Symptoms of diabetic reaction:

a. Glass-eyed appearance.

b. Fuzziness and lack of response to simple questions.

c. Lack of balance.

d. Loss of muscle control causing him to fall to the ground.

e. If this happens, Tim should ask for juice or sugar. Also suggest that the staff not respond until it appears that Tim cannot manage the reaction himself.

9. If diabetic reaction causes a disruption in school, he should be taken out.

To review the actual goals established by the Children's

Farm Home, a review of the Children's Services Division record was done. The narrative indicated that the plan was to help Tim gain enough skills to live independently. The writer assumed that skills meant educational, vocational and medical self-management; although the case record did not elaborate them as such. Based on these goals, the writer also assumed that independent living was to be the eventual plan for Tim's adulthood.

Two main goals of the Children's Farm Home were: (1) To help Tim learn to manage his diabetes so that he would not use it to manipulate. It is significant to note that this is the same goal established nine years earlier. (2) To develop a sense of pride and 
self-esteem. In order to do this the plan called for crediting Tim with as many positive accomplishments as possible.

It is important to note some observations and reports made since Tim was placed at the Children's Farm Home on February 16 , 1976: In addition to reviewing written reports, the author made a site visit to the Children's Farm Home on July 27, 1976. It was discovered that Tim had run from Children's Farm Home on at least three occasions, usually going to the University of Oregon Medical School in Portland. A run-away was reported on May 27, 1976, at which time Tim was admitted to the hospital. In June of 1976 , Children's Services Division agreed to contact the University of Oregon Medical School to make arrangements for returning Tim to Corvallis after future run-away episodes. The Farm Home made the statement that the present staffing pattern was inadequate to deal with Tim's behavior, even though the original plan was to hire staff to provide continuous one-to-one supervision. The purchase of care contract also specified that Children's Farm Home would provide "continuous supervision and monitoring of child because of self-destructive tendencies." The present staff of Unruh Cottage is three staff on weekdays on the 3:00 p.m. to 11:00 p.m. shift and two staff on weekends. There are fourteen residents at Unruh Cottage. Another observation of Tim was made by the consulting psychologist. He stated that, "Tim was more fearful of others 
around him with less feeling of having any support figures there, perhaps contributing to his run-away tendencies."

Tim's school reports were issued in April of 1976, two months after his placement. The reports revealed that he was frequently absent or tardy and had accomplished very little. Mention of erratic behavior in class and major difficulties interacting with his classmates was also made. He received incompletes in Math, Ceramics, English, Woodshop, and Home Economics. Satisfactory marks were given in Physical Education, Communication and Geography.

In reviewing Tim's living quarters, it was noted that he had been moved to an isolated, cement room alone in the basement. Unruh Cottage was a new and very attractive contemporary, natural wood building. In it was a large living area, recreation a rea, kitchen and bedrooms. Each bedroom housed two boys. However, Tim's inability to get along with his roommate had prompted the staff to move him to the basement. The staff's statement was that this type of negative reinforcement would be beneficial to Tim and that he would want to change his behavior so that he could move back to a regular room.

One must consider how Tim could be expected to develop good peer relationships while living alone in the basement. Children's Farm Home made the statement to Children's Services Division in 
May of 1976 that Tim's severe problems required special treatment which tended to isolate him from good peer relationships. This message was sent by a social worker at Children's Farm Home to The Children's Services Division.

On June 7, 1976, in a meeting between Children's Farm Home and Children's Services Division the treatment plan was revised as follows:

1. Home visits with the staff member of Tucker Cottage would be gradually discontinued while at the same time Tim would be introduced to a foster home situation near Corvallis.

2. Because Tim is fearful of his peers and of physical contact with them, he should remain on visual supervision constantly with the staff until he becomes more comfortable with his peers.

Both parties at the meeting agreed that the number one treatment objective at the present time was the development of peer relationships. To accomplish this goal, group the rapy would take place once a week.

It is evident that the means utilized to secure placements were those having to do with political bargaining and negotiating. Also utilized were attempts to convince agencies of Tim's positive aspects and previous developmental progress, while at the same time allowing agencies to use his negative behavioral problems to negotiate for special payment authorizations. 
The researcher also discovered that ultimately the only agencies which established any meaningful, long-term treatment goals were residential treatment centers, particularly Tucker Cottage. No evidence was found which indicated that Children's Services Division, the agency ultimately responsible for Tim's well-being, was actively involved in setting treatment goals. 


\section{CHAPTER VII \\ OBSERVATIONS AND CONCLUSIONS}

When generalizing conclusions of this study it can be said that residential treatment is very expensive; that it attempts to provide more than custodial care and that the clients of the treatment center are removed from the eyes of the public. All of these conclusions are pertinent to the subject of this study. In addition to these general conclusions, numerous specific observations and conclusions have been made. These specific findings will be the subject of this chapter.

An initial conclusion is that Tim is an appropriate candidate for residential treatment. Even though this treatment method is generally considered to be the treatment of last resort, it was basically the only option available to the Children's Services Division. The only exception may have been a more vigorous attempt to locate a suitable foster home in October of 1975 when the specialized foster care rate was approved. As previously discussed, the residential treatment method is considered to be most appropriate for emotionally disturbed adolescents with multitudinous problems. Tim most certainly was an appropriate candidate using this criterion. 
His case was indeed a difficult, perhaps even impossible, one to deal with. The residential treatment centers were asked to compensate Tim for his early childhood emotional deprivations and to prepare him for adulthood. This task is most difficult when compounded by the fact that there has been no natural support system available to Tim. Consequently, the treatment centers have been forced to focus on the behavioral manifestations of the identified problems, namely the acting-out and self-destructive behavior. The treatment centers have also had to deal with the diabetic condition and the effects that it has on one's emotional adjustment. Perhaps additional consideration would have been given to assessing this aspect of the case in terms of its emotional effects. Much evidence was found pertaining to ways of handling the outward manifestations of the diabetes. Specific instructions regarding diet and how to deal with diabetic reactions are two examples of treatment recommendations. However, no evidence was found in diagnostic summaries regarding the emotional impact of adolescent diabetes. This information would seem to be a most important component to consider when developing treatment goals. :

Another conclusion drawn is that there has been no consistency with respect to placement and treatment modalities since Tim was originally placed in the custody of the Children's Services Division in December, 1966. The lack of consistency may well 
correlate with the severity of Tim's adjustment reaction with each of his placements. The Tucker Cottage staff continually stressed this need for consistency, particularly during the adolescent years when continuity and consistency are the most difficult. Tim's adolescent adjustment reactions and rapid body changes were further complicated by his diabetes.

During his adolescent years Tim was placed in the residential treatment center in Florida, detention centers, Tucker Cottage, and Children's Farm Home. He additionally had no parental values to adopt as a model, or any successful peer relationships. He had no feeling of being accepted or valued by either adults or peers. Consequently, he could not only be called disturbed but also neglected.

The residential treatment center's efforts to develop peer relationships, in this case, would appear to be most appropriate. However, there is no evidence to substantiate that the re has been any degree of success. Reports indicate he had no satisfactory peer relationships in 1973 and continue to indicate none at present. Seventeen placements in a period of nine years and eight months seems to be mutually exclusive with treatment goals aimed at the development of meaningful interpersonal relationships and the development of social skills and peer relationships.

The reports from Tucker Cottage during the placement process to Children's Farm Home indicated that progress had been 
made in accomplishing these goals. However, Children's Farm Home continues to indicate that these specific goals are still not accomplished. This raises the possibility of some regression brought on by the move to Children's Farm Home or that the Tucker Cottage staff was more optimistic than realistic in their evaluative reports.

A most significant revelation of the study is the amount of money authorized for purchase of care. One must ask what $\$ 74,767.90$, plus the additional expenses, has bought. To answer, it becomes necessary to examine the diagnostic summaries made in 1967 and those in 1976, remembering that the financial figure is for the period from May 25, 1973 through July 31, 1976. The diagnostic impressions are essentially unchanged from nine years earlier. This is also true of the manifested behavior. The treatment plans continue to address the same goals. The staff of Tucker Cottage say there has been positive growth. However, Children's Farm Home staff say the behavior is unchanged. Evidence such as continued run-away episodes, self-destructive behavior, manipulative behavior related to the diabetes, poor academic adjustment, no peer relationships or social skills, and the continuing need for constant one-to-one supervision all tend to validate the claims of the Children's Farm Home. It must also be remembered that it is because of the negative behavior that Children's Farm Home 
received $\$ 1,984.98$ per month in purchase of care fees through July $31,1976$.

A question remaining unanswered is whether any monitoring of the treatment components of the residential centers is done by the contracting agency, namely, Children's Services Division. The Children Services Division monitors the financial aspects of purchase of care and requires periodic progress reports on the children in residence. These activities plus licensing reviews of the physical plant could perhaps be augmented by evaluative reviews of the treatment components of the programs. The public is entitled to such accountability from the service providers. Logically, the responsibility for this monitoring could not be the responsibility of first-line Children's Services Division staff who are responsible for individual residents of the facility. It would seem to be mutually exclusive to assume the role of providing direct services and also monitor all programatic aspects of a program.

Another conclusion is that there has been no enforcement of the specific contract agreed to for Tim. Because the Children's Farm Home initially stated that the staffing pattern was inadequate to deal with Tim, additional funds were provided to ensure "continuous supervision and monitoring of the child because of selfdestructive behavior." However, even with the additional monies to increase the staff, the Children's Farm Home stated, following 
the May, 1976 run-away episode, "The present staffing pattern is inadequate to deal with Tim's kind of behavior." The contract also states that the re will be "special training for regular and relief staff." It must be remembered that $\$ 1,102.00$ per month in additional funds were approved to purchase these specific special services.

A most pertinent question coming out of this study is, "Where is Tim going? What happens when he reaches the age of legal emancipation and is suddenly an adult?" This date is two and one-half years away. Children's Farm Home has an extremely pessimistic outlook. Tim has few academic skills, no vocational interests, has an extremely fragile physical condition, and has no skills to develop meaningful, growth-producing interpersonal relationships. For nine years and eight months, Children's Services Division has been responsible for Tim. Thousands of dollars and hours have been expended. One obvious result is that at eighteen Tim will become the responsibility of another division, perhaps Mental Health or Corrections. Children's Farm Home complained about the lack of planning for after-care on the part of the Children's Services Division. The job description for liaison unit casework lists the following under "After Care:"

1. Caseworker makes plan in conjunction with the child-care agency. 
2. Caseworker finds substitute placement. (foster care, group care)

The reality of 'Tim's situation is that no one is thinking about after-care, only about maintaining the present placement. Even though Children's Services Division policy calls for case transfer from the liaison unit when the placement is a long-term one, no case transfer has occurred. Tim's placement is a long-term one. A guarantee of a long-term placement was made to Children's Farm Home during the placement negotiations.

Perhaps if planning for after-care could begin now, the notoriety, publicity, and bargaining, which took place during the last placement, could be reduced. Putting Tim's situation before the public has historically been an effective means used to apply pressure to guarantee a placement. Specific examples of this relate to the Florida placement and the formation of the Child Advocacy Committee. This publicity has also helped residential treatment centers to substantiate their demands for payment rates. One plan developed by Tucker Cottage included contacting The Oregonian and Oregon State legislators to act as advocates for Tim. This type of planning raises serious questions concerning dignity and privacy,

In summary, it can be said that an enormous amouth of time, energy, and money have been spent for Tim, yet little has 
changed in nine years and eight months. He continues to be a disturbed and neglected person. The residential treatment center staffs and many others involved appeared to be genuinely concerned with his welfare. Honest efforts were made on his behalf. Despite these efforts, there does not appear to be a bright light at the end of the tunnel. 


\section{BIBLIOGRAPHY}

\section{WORKS CITED}

${ }^{1}$ American Association for Children's Residential Centers, From Chaos to Order: A Collective View of the Residential Treatment of Children, Child Welfare League of America, New York; 1975 , p. 1 .

\section{$2_{\text {Ibid. , p. } 37 .}$}

${ }^{3}$ Bettleheim, Bruno, A Home for the Heart, Alfred A. Knopf, New York, 1974, p. 27.

${ }^{4}$ Murphy, Lois Barclay, Growing_Up in Garden Court, Child Welfare League of America, 1974, p. 50.

${ }^{5}$ Martin, L. H.; Pozdnjakoff, I.; Wilding, J., "The Uses of Residential Care", Child Welfare, Vol. 55, No. 4, April 1976, p. 270 .

${ }^{6}$ Murphy, p. 62

${ }^{7}$ Good, Dorothy, and Al-Saadi, Luetta, Help Me, Thomas Publications, Wisconsin, 1970, p. 52.

${ }^{8}$ Bettleheim, p. 46 .

${ }^{9}$ D'Amato, Gabriel, Residential Treatment for Child Mental Health, Charles C. Thomas, Illinois, 1969, p. 128.

$10_{\text {Ibid., p. } 128 .}$

${ }^{11}$ American Association for Children's Residential Centers, p. 36 .
12 Murphy, p. 160.
13 Bettleheim, p. 211 . 
${ }^{14}$ Murphy, p. 174.

${ }^{15}$ Bettleheim, p. 137.

${ }^{16}$ Hylton, Lydia, F., The Residential Treatment Center, Children, Programs and Costs, Child Welfare League of America, Inc., 1964, p. 169.

$\int_{\mathrm{p}} 85 .{ }^{17}$ American Association for Children's Residential Centers,

${ }^{18}$ Geist, Harold, The Psychological Aspects of Diabetes or How To Live in Emotional Balance with Diabetes, Charles C. Thomas Publisher, Springfield, Ill., 1964, p. 39.

${ }^{19}$ Ibid., p. 39.

20 Wenar, Charles, Personality Development, Houghton Mifflin Co., Boston, 1971, p. 384. 


\section{REFERENCES}

Ackerman, Nathan W. Family Process, Basic Book, Inc., New York, 1970.

American Association for Children's Residential Centers. From Chaos to Order: A Collective View of the Residential Treatment of Children, Child Welfare League of America, New York, 1975.

Bettelheim, Bruno. A Home for the Heart, Alfred A. Knopf, New York, 1974.

Colbath, Loris; Graf, Carolyn; McKinnon, Carol; and Newcomb, Jean. A Study of Runaways From Six Residential Treatment

Agencies, M.S. W. Practicum, Portland State University, 1975.

D'Amato, Gabriel. Residential Treatment for Child Mental Health, Charles C. Thomas, Illinois, 1969.

Dickey, Joan. Criteria and Outcome of C.S.D. Foster Home and Residential Placements of Court-Referred Adolescents, M.S.W. Practicum, Portland State University, 1975.

Erikson, Erik. Identity and the Life Cycle, "Psychological Issues", New York, International Universities Press, 1959.

Fisher, Alfred E., and Horstmann, Dorthea L. A Handbook for the Young Diabetic, International Medical Book Corporation, New York, 1964.

Gejist, Harold. The Psychological Aspects of Diabetes, Charles C. Thomas, Springfield, Illinois, 1964.

Goos, Dorothy, and Al-Saadi, Luetta. Help Me, Thomas Publications, Wisconsin, 1970.

Hytton, Lydia F. The Residential Treatment Center, Children, Programs and Costs, Child Welfare League of America, Inc., 1964.

Kahan, V.L. Mental Illness in Childhood, Tavistock Publications, J. B. Lippincott Co., 1971. 
Martin, L. H.; Pozdnjakoff, I. ; Wilding, J. "The Uses of Residential Care", Child Welfare, Vol. 55, No. 4, April 1976.

Mayer, Goetz, and Pearson, James. "Social Control in the Treatment of Adolescents in Residential Care: A Dilemma", Child Welfare, Vol. 54, No. 4, April 1975.

Murphy, Lois Barclay. Growing Up in Garden Court, Child Welfare League of America, 1974.

Wenar, Charles. Personality Development, Houghton Mifflin Co., Boston, 1971. 